\title{
Reforms Supported by the Reformers
}

\author{
Anatoly G. Kasprzhak, \\ Rustam F. Bayburin and Natalia V. Isaeva* \\ National Research University Higher School of Economics \\ 16/10 Potapovskiy pereulok, Moscow, 101000, Russia
}

Received 14.08.2015, received in revised form 11.09.2015, accepted 29.09.2015

The article discusses the results of the study of the management decision-making styles of secondary school principals, which was held in 2014 in eight regions of the Russian Federation (one region of each federal district) basing on the methodology of A. Rowe. The objective of the study was to assess the Russian principals' reform potential, which in the present conditions, according to the authors, is based on the ability to build a partnership with teachers in decision-making and to preserve the ability to solve problems in a situation of uncertainty, which was so characteristic of the era of change.

Based on the findings of the research on the management decision-making styles, comparison of the two reforms in the recent history of Russian education was made: the financial reform that includes certain financial freedom for schools willing to switch to a form of the autonomous institution, and the substantial reform that offers schools to claim to a lyceum and gymnasium status with wider opportunities to organize the educational process. The comparison reveals that the substantial reform has attracted a greater number of principals-reformers than the financial one, which characterizes a formal and directive side of the latter.

Keywords: school principals, school leadership, decision-making styles, reform potential of the education system, reforms in education.

DOI: 10.17516/1997-1370-2015-8-11-2458-2468.

Research area: pedagogy.

\section{Introduction}

In recent years the Russian educational system involved a series of reforms in the field of organizational and financial conditions for the functioning of educational institutions. First of all, it is the transfer of schools into a status of budgetary and autonomous institutions, the introduction of legal and budgetary financing, a new wage system. The possibilities of a school to obtain a new status - a gymnasium or a lyceum increase school's responsibility not only for finances, but also for the results of education.

Such changes quite naturally raise the question on a principal as a conductor of lawmakers' plans in school, a key figure that should or should not approve the basic ideas of the new Russian school, thus determining its fate. In this context, school leaders and their management teams are seen as agents of change, the main driving force for the upcoming changes.

A position of a principal has changed fundamentally over the past 10-20 years. If

(C) Siberian Federal University. All rights reserved

* Corresponding author E-mail address: agkasprzhak@hse.ru,rbaiburin@hse.ru,nisaeva@hse.ru 
in the last years of the Soviet regime a school principal was liable to the government for the implementation of the general education of children and for the quality of training, then in the post-Soviet period he was forced to deal with a lot of material and financial problems, but was free to choose an educational strategy for his institution. In the mid-1990s, L.I. Fishman identified in his study a cluster of "traditional progressive leaders" that included $72 \%$ of principals (in total, 282 school principals in three regions of the Russian Federation were surveyed). These principals were characterized by the focus on achieving educational results and organization of collaborative work with teachers, delegation and allocation of liability between them. (Fishman, 1999). One of the largest empirical studies of that period was the Mann's and Briller's study of opinions of 1400 principals from six regions of Russia, the aim of which was to identify an innovation potential of school principals. According to the results, $1.5 \%$ of the respondents saw a need for a management reform, knew how to carry it out and were ready to do it. The majority (40\%) identified themselves not as the reformers, but as the innovation-oriented toward the best examples.

20 years have passed. How has the innovation potential of principals changed and who, now, can be attributed to the drivers of change in education? Considering a current principal as the key agent of change, we have tried to estimate his reform potential and observe the recent significant educational reforms from this angle.

The object of the analysis in this study is the principals of secondary schools in eight regions of the Russian Federation, and the subject of the research is a management decision-making style of principals.

The purpose of the study is to identify, based on the results, whether the educational reforms carried out in the recent history of our country are supported by the principals of schools with that reform potential. Two reforms are considered: a financial reform that implies certain financial freedom for schools willing to switch into the form of an autonomous institution, and a substantial reform that offered schools to qualify for statuses of lyceums and gymnasiums with more opportunities of organization of the educational process.

\section{Leaders and reformers in education}

Anactive study of the leadership phenomenon in education began in the $60 \mathrm{~s}$ of the $20^{\text {th }}$ century in the U.S. Until the 1980s, school principals had been considered exclusively as "hierarchical administrators" set into rigid management schemes with clear allocation of functionality within an institution (Ogawa, Bossert, 2000).

Since the 1980s, the focus of research has shifted sharply to the study of a principal as a person responsible for the educational achievements of students. A new concept of an "instructional leader" emerges (Schein, 1992; Edmonds, 1979). As was noted by K. Leithwood, et al (Leithwood, Jantzi, Steinbach, 1999), now the principals must not only efficiently manage material and financial infrastructure of schools, but mainly focus directly on the educational process by supporting the work of teachers and their classroom behaviour that directly depends on the achievements of students. A principal also became an expert in the field of development and implementation of educational (training) programs. P. Hallinger and R. Heck conducted a meta-analysis of studies of school leadership and, as a result, came to the conclusion that most of them revealed dependence of the activity of a manager in creating a common vision and mission of a school among the teaching staff and the level of student achievements (Hallinger, Heck, 1998). It is the leadership characteristics of the principal that are predictive of the performance of students, 
on the one hand (Witziers, Bosker, Kruger, 2003), and of the successful implementation of innovations (reforms), on the other hand (Hamilton \& Richardson, 1995).

In today's highly dynamic world, in which the nature of challenges faced by a school is constantly changing, there is another paradigm shift. Now a principal becomes a "leader of the team of leaders" who delegates some of his functions to employees expanding their areas of responsibility for the joint development and implementation of a uniform education policy (Shawn, 2009). This expectation is confirmed by the studies of PISA: the report for 2012 (OECD, 2013) states that "schools with a greater degree of involvement of teachers in the management and schools with greater autonomy regarding formation of curriculum and assessment procedures, tend to show better results than schools with less autonomy that are part of the school system with great number of accountability mechanisms." A. Harris calls this type of leadership distributed (Harris, 2008).

What do we mean when we talk about the reformist potential of principals in today's conditions? It means that a leader can identify the main ideas of any reform. He can narrow an excessively broad framework of conceptual texts that underpin the reform by defining what exactly and how it can be realized in his school. And, finally, he is able to adopt these innovations.

What are the main indicators of the effectiveness of the reformer-principal? As we have noted, over the past few years our education system has been going through a long series of various reforms. This state of the system can be characterized as a state of deep uncertainty when the basic rules and settings regularly change, and the school is under the pressure of a large number of new objectives. In such conditions only principal can successfully cope with affairs with a high level of tolerance to situations of uncertainty. Otherwise, the reform will be implemented in failure or introduced formally. So, the first indicator of effectiveness is the ability to work in a situation of uncertainty.

We also mentioned above that due to the educational reforms and greater freedom, the responsibilities of the school principal in recent years significantly increased adding the objectives of instructional leadership to the administrative and economic objectives. Thus, the principal has to deal with more affairs than one person can effectively carry out. It emphasizes an obligatory ability to delegate power (in the terminology of A. Harris - distributed leadership). This is the second indicator.

And we noticed that a person with a given set of skills is accurately defined in the methodology of Alan Rowe (Reardon, Reardon, Rowe, 1996) as a person with a conceptual style of management decision-making that can operate effectively in a situation of uncertainty and in cooperation with his team. That is why our research focuses on the use of the conceptual style of decision-making by school principals.

\section{Methodology and research}

Styles of management decision-making by school principals in this study were assessed using the methodology of A. Rowe (Reardon, Reardon, Rowe, 1996). It is applicable for the assessment of styles of decision-making in all professional fields, including education. Proof of the broad possibilities of the methodology is the works of its author, in which he compares, for example, managers and architects (Rowe, Boulgarides, 1983). The validity of the application of this methodology is confirmed, in particular, in the study of principals of secondary schools held in the Canadian province of New Brunswick (Williams, 2006).

There was a survey of principals conducted in eight Russian regions (one region in each federal 
district). Without claiming for representativeness of the data in relation to the general community of school principals in Russia (as of September 1, 2014 there are more than 40 thousand people), we have analyzed the objective characteristics (gender, age, education, experience and so on) of principals with the dominant conceptual style of decision-making. According to the classification of A. Rowe they are characteristic of tolerance to a situation of uncertainty and focus on people in the course of solving problems of high cognitive complexity. Therefore, we came up with a "portrait" of a principal having a reformist potential.

Having highlighted key events that have occurred in the education system of Russia in the last 20 years and having studied the decisionmaking styles that are typical for administrators of school that have changed their status or legal form, we attempted to assess the reform potential of the administrative action itself. As such, we have selected the following actions:

- transition to specific originality of schools, which resulted in the allocation of lyceums and gymnasiums;

- schools' acquisition of the status of autonomous, budgetary and public institutions.

A hypothesis of the study was that the school status change was carried out by the reformersprincipals who were able to understand and accept the reform ideas and to implement them together with the teaching staff, parents and partners.

The empirical data were collected in eight regions: Samara Region (Oblast'), Novosibirsk Region, Yaroslavl Region, Stavropol Territory (Krai), Khabarovsk Territory, Krasnodar Territory, Perm Territory and Saint-Petersburg. In St. Petersburg we conducted a survey of school principals in two districts -Krasnoselsky and Vasileostrovsky (67 educational institutions). In other regions 200 schools out of the total number of educational institutions were randomly selected. In the context of an unequal number of educational institutions in the regions-participants of the study, from a sociological point of view, the sampling that included 200 schools was appropriate to achieve both the representativeness of data for a region and the comparability of data between the regions.

An online survey for all the participants was built on a web-platform SurveyMonkey, the A. Rowe questionnaire was its basis. The questionnaire included a segment of questions, which allowed us to identify each school and its principal in accordance with several criteria:

- gender, age, professional experience of a principal;

- location of an educational institution (city/village);

- form of ownership (state, municipal, private);

- number of classes;

- type of organization (budgetary, governmental, autonomous);

- type oforganization(lyceum, gymnasium, etc. $)^{1}$.

The A. Rowe's questionnaire presents 20 questions (some kind of administrative cases). For each question there are four possible answers that correspond to the management decision-making styles allocated by A. Rowe: directive, analytical, conceptual and behavioural. A respondent should assess how each option is typical for his management activities giving them 1, 2, 4 or 8 points, where 1 corresponds to the option least peculiar to the respondent, and $8-$ to the most peculiar. The points for each style are summarized and parameters of the respondents' use of each of the four styles of management decision-making are defined.

The next step is to determine which of the styles are dominant and auxiliary for the respondent, and which of them he avoids in his practice (in accordance with the methodology of 
A. Rowe, a person can have several dominant, auxiliary or avoidable styles at the same time). To assess a particular style by a degree of the respondent's use we calculated an average value for a given style of the entire sampling (n) and a mean square deviation $(\sigma)$. In the range of $\left[\mathrm{n}-\frac{\sigma}{2} ; \mathrm{n}+\frac{\sigma}{2}\right]$ there are values corresponding to the auxiliary decision-making style. To the right of this range there are values of the dominant style, and to the left - values of the avoidable style.

For example, for the target population of data the mean value on the directorial style is equal to 75.2 , and the mean square deviation - to 13.4. Then the managers, whose level of use of the directorial style is in the range $[68.5 ; 81.8]$, have this style in their arsenal as auxiliary. Those principals, whose level of use of the directive style is above 81.8 , actively use this style in decision-making. Finally, with respect to the respondents who showed the level of the decision-making style below 68.5 , it is concluded that they try to avoid directive methods in the management work. Furthermore, in order to reveal the specifics of a given sampling (e.g., city principals with huge experience), it is sufficient to calculate the proportion of respondents belonging to a certain interval of indicators for each of the four styles.

\section{Reformist potential of Russian principals ${ }^{2}$}

There were no significant differences in the distribution of styles of decision-making among the principals in the regions of the survey. In each of the eight regions the principals use all four styles of management decision-making (as main, auxiliary and avoidable), at this, the proportion of each style as the dominant one ranges from 20 to $30 \%$ (Fig. 1). The findings, in our view, put into question the widespread expert statements, according to which the Russian principals are becoming more directive recently.

Since there are no regional differences in the distribution of decision-making styles among school principals, we continue the analysis of the entire group of respondents as a solid block.

The reformist potential of principals was assessed on the basis of the proportion indicators of the school principals that use the conceptual style of management decision-making as the main or avoid it.

The data presented in Fig. 2 show that about one-third of principals of both genders in eight

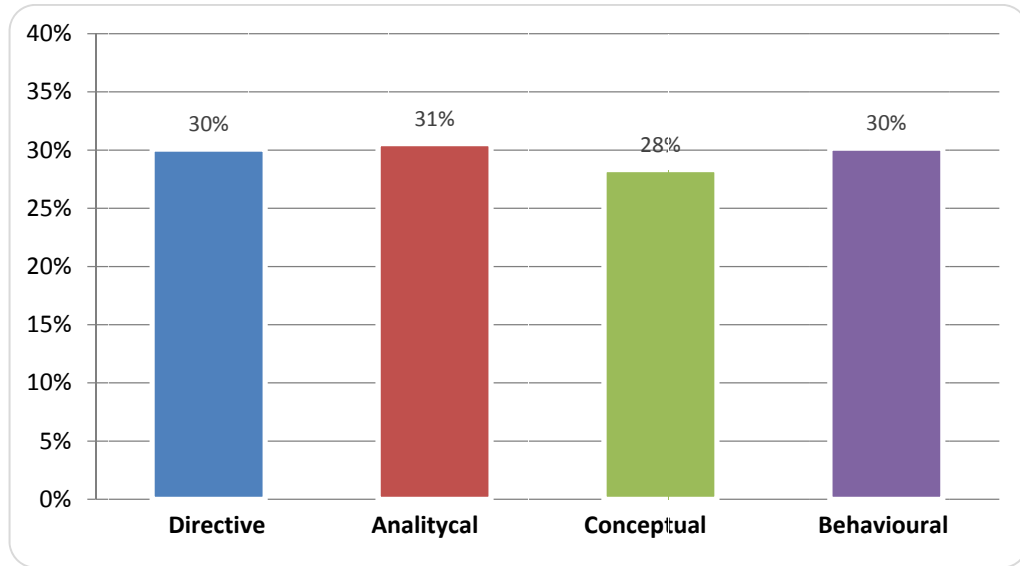

Fig. 1. Total sampling distribution of principals on the basis of the dominant style of management decisionmaking (\%) 


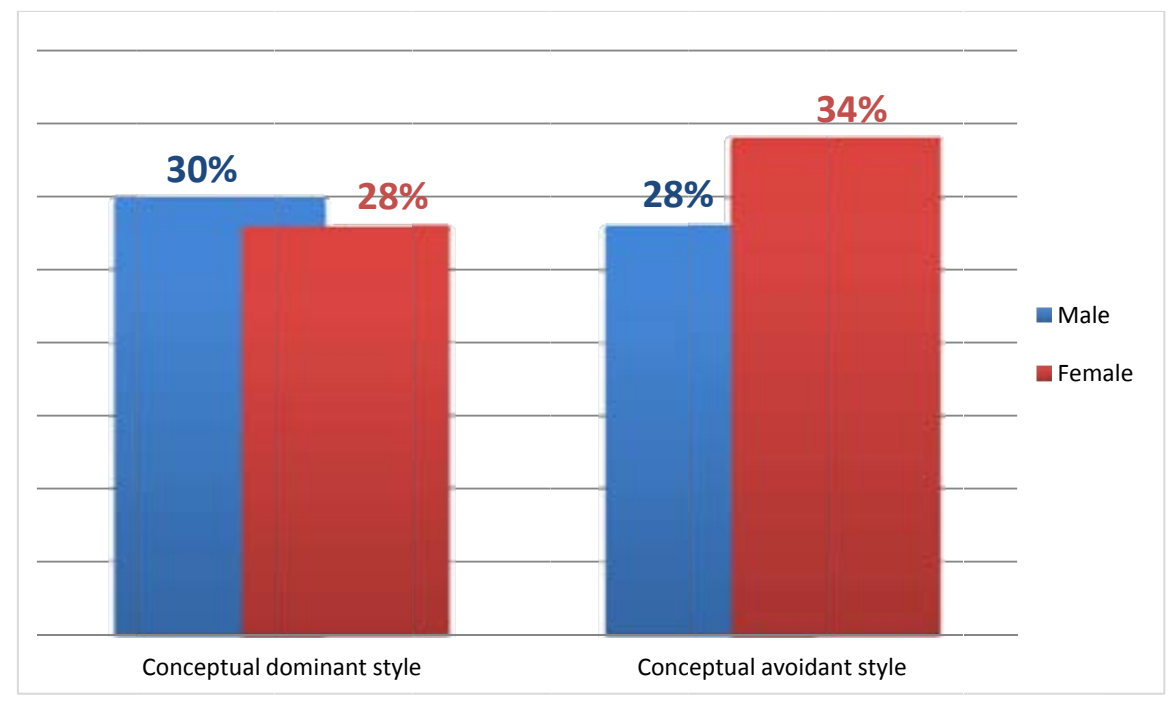

Fig. 2. Differences in the reformist potential of principals by gender (\%)

regions of Russia prefer to use the conceptual style in their management practices, and almost the same proportion of school administrators avoid this style. No significant differences in this parameter between female leaders and their male counterparts were found.

The results shown in Figures 3 and 4 prove that the conceptual style of decision-making develops over the years, with experience. Consequently, the search for agents of reforms should be among the principals, whose management experience is more than 20 years. The principals with experience of for more than 20 years got this job until 1994, i.e. in the period of changes, and it is only them who have the reformist potential.

The more students in school, the higher the probability that the principal adheres to the conceptual style of decision-making, and the less likely he avoids this style (Fig. 5). Apparently, small teams are generally controlled by some other, not "managerial", but family laws. $34 \%$ of principals of schools, the size of which is between 19 and 24 classes, and $38 \%$ of principals of large schools (more than 25 classes) constitute the reformist potential of the Russian education system. So, the conceptual style of decisionmaking is a style of "big leaders", i.e. heads of large organizations.

Almost half of the principals of lyceums and gymnasiums have the conceptual style of decision-making, and only 10-15\% of them avoid this style (Fig. 6). On the basis of these data together with the findings regarding age and experience of the principal, it can be assumed that a significant proportion of principals of lyceums and gymnasiums that are usually formed from schools with in-depth study of some subjects showed its reform potential by this very action. Those leaders who did not have such potential have retained the status of their organizations.

We have formulated a hypothesis that the genuinely reformist actions of the federal authorities (occurrence of variation of education and changes in the legal form of educational institutions) have to suggest reformers for the position of principals of schools, i.e. as a result of reforms in the institutions of a new type and the organizations that received financial independence, the leadership must come to the leaders who are not afraid of change. To test it, we 


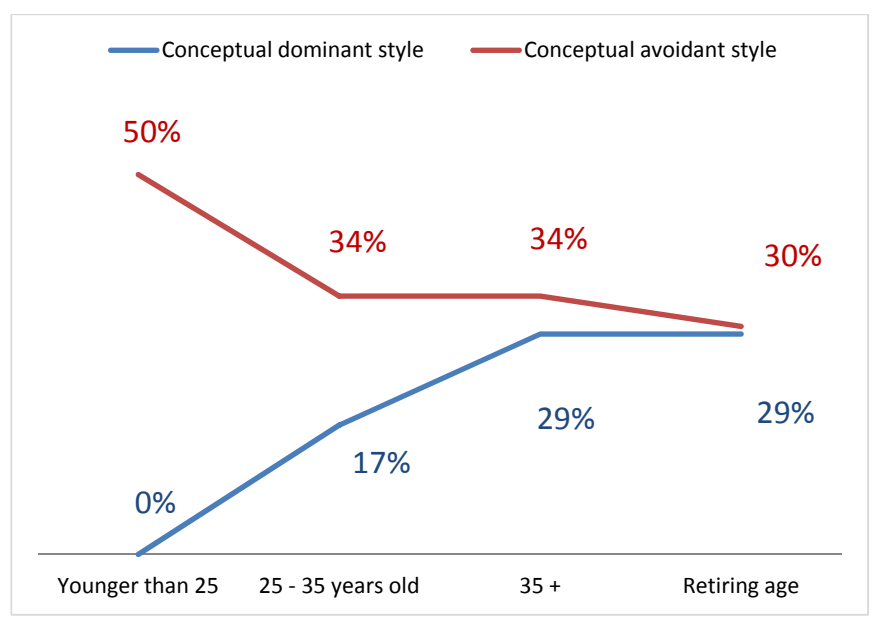

Fig. 3. Evaluation of the reformist potential of principals by age groups (\%)

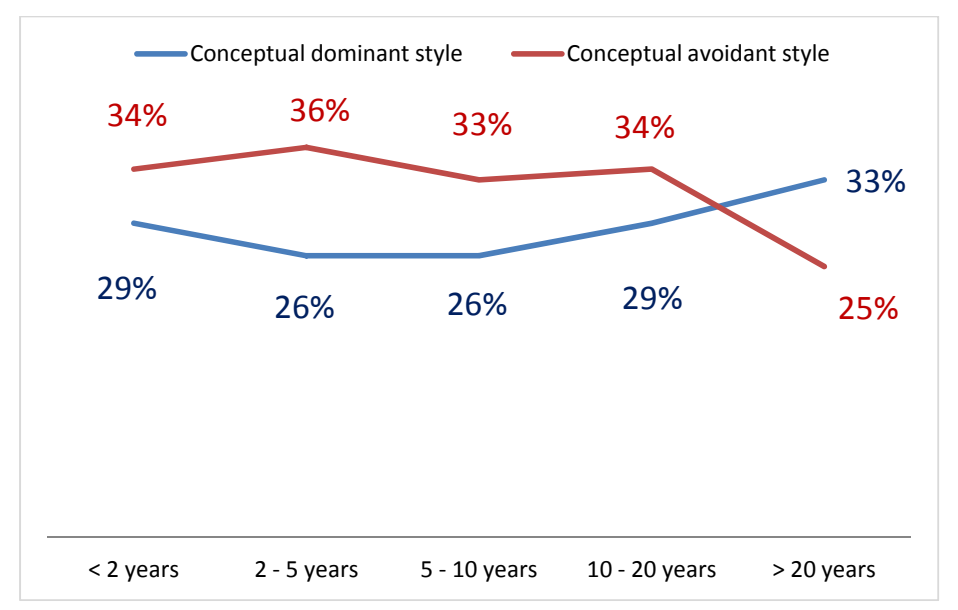

Fig. 4. Evaluation of the reformist potential of principals by the experience of administrative work (\%)

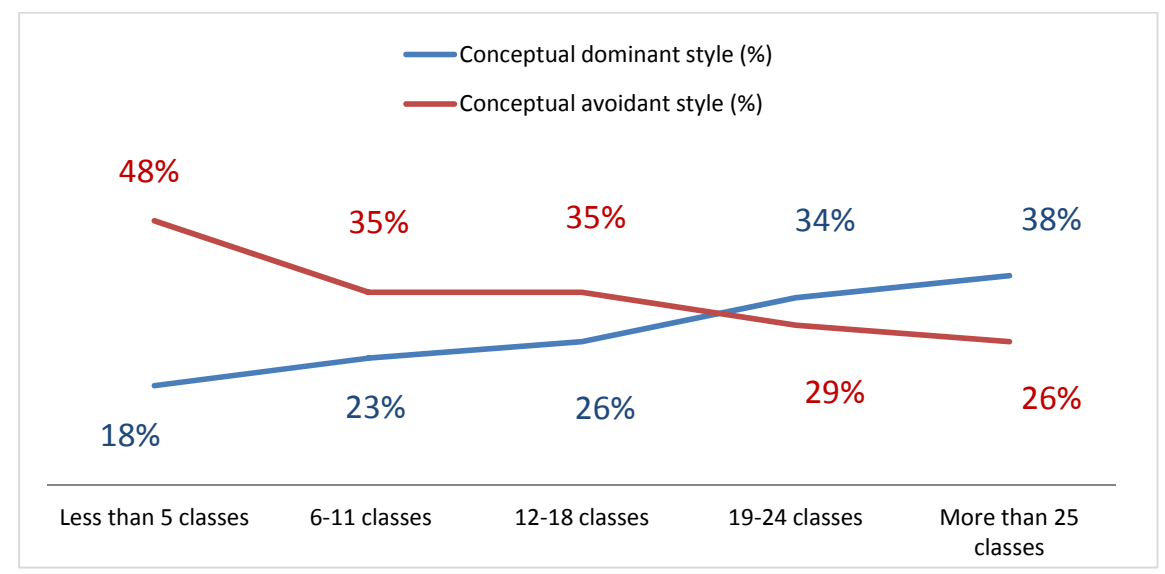

Fig. 5. Evaluation of the reformist potential of principals on the basis of the size of school (\%) 
- Conceptual dominant style $(\%)$

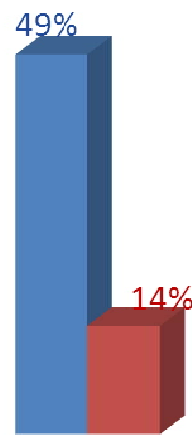

Gymnasium

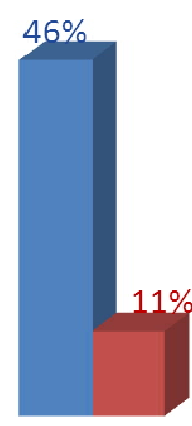

Lyceurn
- Conceptual avoidable style (\%)

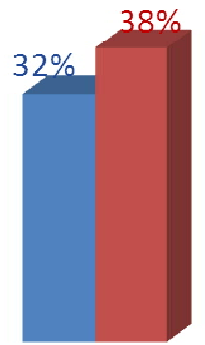

Schools with indepth study of certain subject

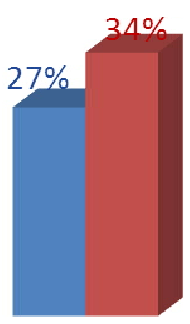

Other

Fig. 6. Evaluation of the reformist potential of principals of educational institutions of various kinds (lyceums, gymnasiums, schools with in-depth study of specific subjects, etc.) (\%)

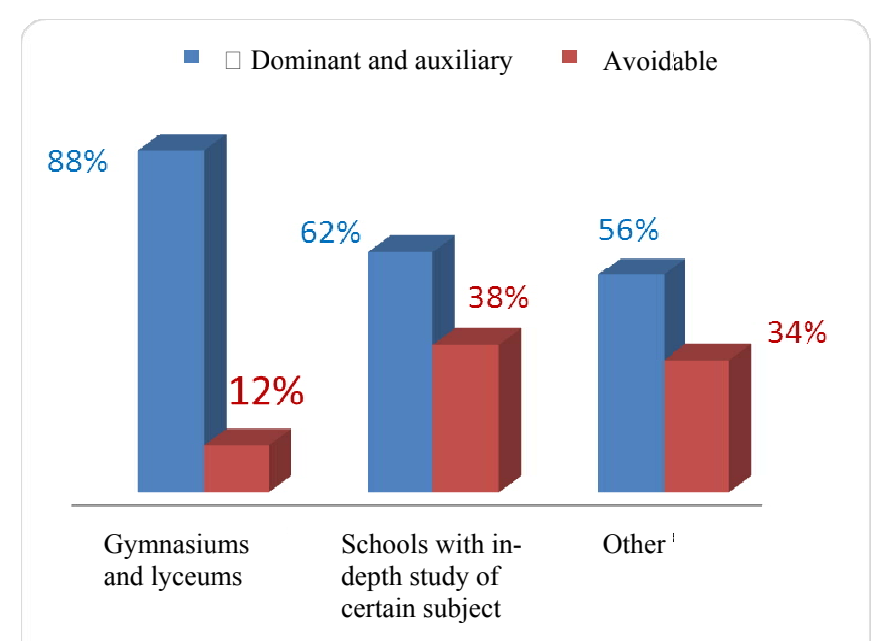

Fig. 7. The principals' use of the conceptual style of decision-making in schools of different types (with different status, \%)

have identified a group of leaders of gymnasiums and lyceums that made the transition to a new status, which was due to the need to develop a new educational program ensuring higher quality of education, etc. The first group included the principals practicing the conceptual style of decision-making as dominant, the second one included the principals having it in their managerial arsenal as auxiliary, and the third group included those who avoid the conceptual style (Fig. 7). The groups of leaders who took on certain financial freedoms and obligations formed in the same way - they moved into the status of autonomous educational institutions that gives the principals a greater managerial authority (Fig. 8).

Almost $90 \%$ of the principals of gymnasiums and lyceums use the conceptual style as the main 


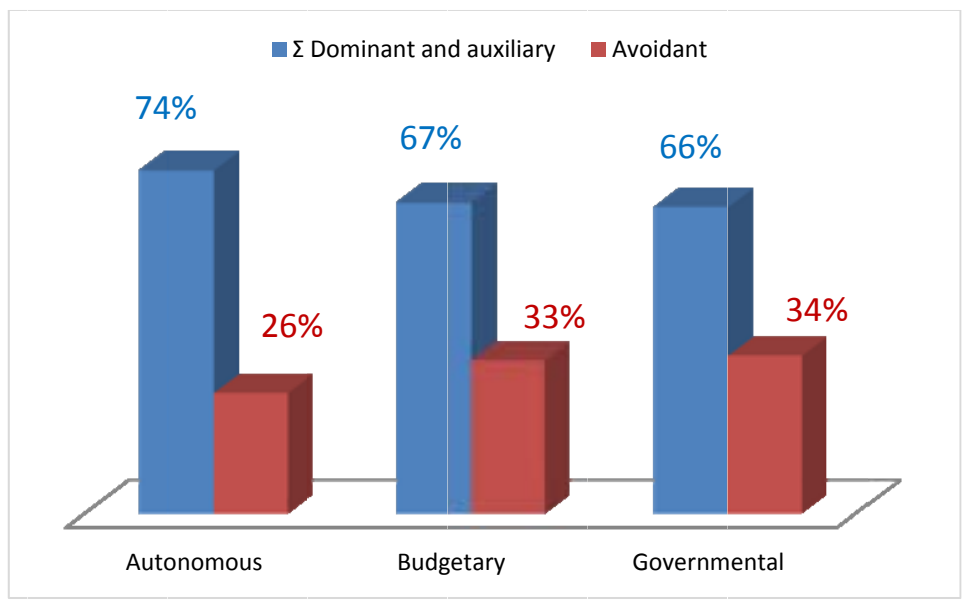

Fig. 8. The principals' use of the conceptual style of decision-making in educational institutions of different types $(\%)$

or auxiliary (Fig. 7). The principals of schools with in-depth study of specific subjects are behind them on this indicator by $26 \%$.

If we analyze the allocation of principals by the school type that determines the degree of financial independence, we will find that the principals of autonomous institutions do not have an acute commitment to the conceptual style of decision-making (Fig. 8). The difference between the principals of autonomous and budgetary schools is only $7 \%$.

\section{Conclusion}

The level of the reformist potential of school principals in the surveyed eight regions of the Russian Federation was determined on the basis of the proportion of managers using a conceptual style that is characterized by a high degree of tolerance to a situation of uncertainty and solving of problems of high cognitive complexity, in other words, the possibility to adapt a reform to the level of organization. These studies have shown that most of the leaders are not ready to act in a situation of uncertainty that is an attribute of any changes. The reasons for this state of affairs are the subject of a separate study.
If we compare the consequences of two reformist action - the introduction of variability and provision of schools with financial freedom then we can say that their results turned out to be different. If the substantive reform (variability) attracted the attention of reformers (that is where they were in demand), then the financial reform took place not due to the willingness of school leaders to take on a new level of responsibility in exchange for new opportunities, but because of the need to implement the state policy. "Thus, in decision-making regarding schools the autonomy does not allow a principal to become a reformer" (OECD, 2009).

As shown by our study, the economic orientation of reforms, on which the emphasis was given in the Russian education system in the last 10-15 years, could not demonstrate the reformist potential of principals in full. In part it can be explained by the fact that the content of the reform itself does not correspond to the modern concept of leadership in education: it does not directly concern the issues of organization of education (instructional leadership) and the issues of interaction and division of responsibilities within the teaching staff (distributed leadership). The 
substantive reforms are able to push the school principals to develop their leadership skills and to use their reformist potential, so such government actions as the introduction of a new federal state educational standard, professional standard of a teacher give rise to a slight optimism.

\footnotetext{
See the online survey: https://ru.surveymonkey.com/r/6WK8FPM

The authors would like to thank the Dean of the Faculty of Business and Management of the HSE Filinov N.B. and a research associate of the Center for Leadership Development in the formation of the Institute of Education of HSE Bysik N.V. for the productive discussion of research results; students of the Faculty of Management of HSE Bushueva E. and Kalinkina G., as well as an intern researcher of the Center for Leadership in Education of the Institute of Education of HSE Shevtsov D.A. for assistance in organizing the collection and initial processing of the principal survey data in eight regions of the Russian Federation.
}

\section{References}

Edmonds, R. (1979). Effective Schools for the Urban Poor. Educational Leadership, 37(1), 1524.

Fishman, L.I. (1999). Sovremennyi direktor: professional'nye tsennosti i stereotypy (okonchanie) [Modern Principal: professional values and stereotypes (conclusion)] Principal of a school, 6, 8-14.

Hallinger, P. \& Heck, R.H. (1998). Exploring the Principal's Contribution to School Effectiveness: 1980-1995. School Effectiveness and School Improvement, 9(2), 157-191.

Hamilton, M.L. \& Richardson, V. (1995). Effects of the Culture in Two Schools on the Process and Outcomes of Staff Development. The Elementary School Journal, 95(4), 367-385.

Harris, A. Distributed Leadership. Developing Tomorrow's Leaders. London, Routledge, 2008.

Leithwood, K., Jantzi, D. \& Steinbach, R. Changing Leadership for Changing Times. Philadelphia, Open University Press, 1999.

Mann, D. \& Briller, V. (1996). Shkol'nye administratory Rossii: glazami amerikanskikh issledovatelei [School administrators in Russia: through the eyes of American researchers]. Headmaster, 1, 12-20; 2, 14-22; 3, 33-38; 4, 22-25.

OECD (2009) Leading to Learn: School Leadership and Management Styles http://www.oecd. org/berlin/43541674.pdf

OECD (2013), PISA 2012 Results: What Makes Schools Successful (Volume IV): Resources, Policies and Practices, PISA, OECD Publishing, Paris.

Ogawa, R.T. \& Bossert, S.T. Leadership as an Organizational Quality. The Jossey-Bass Reader on Educational Leadership. San Francisco, Jossey-Bass, 2000. P. 38-58.

Reardon, K., Reardon, J. \& Rowe, A. (1998) Leadership Styles for the Five Stages of Radical Change. Acquisition Review Quarterly, 1, 129-146, http://www.carterreynolds.com/5_stages_of_ leadership.pdf

Rowe, A.J. \& Boulgarides, J.D. (1983) Decision Styles - A Perspective. Leadership \& Organization Development Journal, 4(4), 3-9.

Schein, E.H. Organizational Culture and Leadership. San Francisco: Jossey-Bass, 1992.

Shawn, M.T. (2009) Relationship between the Leadership Styles of Principals and School Culture. http://digitalcommons.georgiasouthern.edu/cgi/viewcontent.cgi?article=1269\& context=etd

Williams, R.B. (2006) Leadership for School Reform: Do Principal Decision-Making Styles Reflect a Collaborative Approach? Canadian Journal of Educational Administration and Policy, 53, $1-22$. 
Witziers, B., Bosker, R.J. \& Kruger, M.L. (2003) Educational Leadership and Student Achievement: The Elusive Search for an Association. Educational Administration Quarterly, 39(3), 398-425.

\title{
Реформы, поддержанные реформаторами
}

\author{
А.Г. Каспржак, \\ Р.Ф. Байбурин, Н.В. Исаева \\ Национальный исследовательский университет \\ Высшая школа экономики \\ Россия, 101000, Москва, Потаповский пер., 16, стр. 10
}

В настоящей статье обсуждаются результать исследования стилей принятия управленческих решений директоров общеобразовательных школ, которое было проведено в 2014 г. в восьми регионах Российской Федеращии (по одному региону в каждом федеральном округе) по методологии А. Роу. Целью исследования было оценить реформаторский потенциал российских директоров, который, по мнению авторов, в современных условиях опирается на умение выстроить сотрудничество с педагогами в принятии решений и на сохранение способности решать задачи в ситуации неопределённости, так свойственной эпохе перемен. На основании полученных данных о стилях принятия управленческих решений проводится сравнение двух реформ в новейшей истории российского образования - финансовой, предполагающей определённые финансовые свободы для школ, готовых перейти в форму автономного учреждения, и содержательной - предложившей школам претендовать на статусы лищеев и гимназий с более широкими возможностями организации учебного проиесса. Сравнение выявляет, что содержательная реформа привлекла большее число директоров-реформаторов, чем финансовая, характеризуя, таким образом, формальность и директивность введения последней.

Ключевые слова: директора школ, школьное лидерство, стили принятия решений, реформаторский потенциал системы образования, реформы в образовании.

Научная специильность: 13.00.00 - педагогические науки. 